\title{
POŠTA
}

TELEKOMUNIKACIE A

ELEKTRONICKY OBCHOD

\section{HLADANIE MEDZNEJ MIERY AKCEPTÁCIE INTERNETOVEJ REKLAMY V PODMIENKACH VYBRANÉHO ZÁKAZNÍCKEHO SEGMENTU - II}

\author{
Vladimíra Žiačková*, Radovan Madleňák*
}

\section{Úvod}

Zmena, ktorou online reklama v poslednom období prešla, sa týka predovšetkým nových možností vyplývajúcich z faktu, že stúpol počet pripojených používatel'ov aj kvalita ich internetového pripojenia. Stúpajúca počítačová gramotnost' má za následok intenzívnejšie využívanie počítačov a internetu, takže používatelia presúvajú čast' svojich povinností a administratívy $\mathrm{z}$ fyzického sveta do prostredia webu (nákupy, finančné operácie, komunikácia, sociálny a spoločenský život atd'.). Výsledkom je, že internetová reklama kopíruje tento pohyb a snaží sa byt' tam, kde jej potenciálni prijímatelia.

Bannerová reklama bola pred niekol'kými rokmi jedinou formou internetovej reklamy, takže sa vôbec nemohlo diskutovat' o špecifických zákazníckych preferenciách v tejto oblasti. Dnes môžeme internetovú reklamu a jej konkrétne druhy považovat' za samostatné odvetvie marketingu, preto je popri ostatných marketingových aktivitách každého podnikatel'ského subjektu neoddelitel'nou súčast'ou úspešnej marketingovej stratégie [3].

Tento článok je priamym pokračovaním článku uverejnenom v tomto časopise: Hladanie medznej miery akceptácie internetovej reklamy $\mathrm{v}$ podmienkach vybraného zákazníckeho segmentu - I.

\section{Metodika}

Pre identifikáciu preferencií používatel’ov bol zvolený ciel'ový segment s názvom „Stredný prúd“. Tento segment bol vybraný kvôli vzorke respondentov, ktorá zahŕňa používatel'ov s rovnomerne rozdelenými charakteristikami. Ide o segment, ktorý zahŕňa $86 \%$ respondentov vo vekovom intervale 20 - 29 rokov, $10 \% \mathrm{v}$ intervale $30-39$ rokov a $5 \% \mathrm{v}$ intervale 40 - 49 rokov. Osoby v tomto segmente sa vyznačujú používaním internetu na nadštandardnej úrovni. Je to najvyrovnanejší segment $\mathrm{z}$ hl'adiska ekonomickej aktivity rovnaké 33 percentné zastúpenie majú osoby v pracovnom pomere, podnikatelia aj študenti. Tvorí ho 48 \% mužov a 52 \% žien [2]. Používatelia zahrnutí v tomto segmente sa s reklamou na internete stretávajú často, takže sú dobre oslovitel'nou skupinou. Ale ako ich správne oslovit? Čo ich dokáže na konkrétnom reklamnom prvku zaujat?? Aké sú oblasti ich hlavných

\footnotetext{
* Ing. Vladimíra Žiačková., Žilinská univerzita v Žiline, Fakulta prevádzky a ekonomiky dopravy a spojov, katedra spojov, Univerzitná 1, 01026 Žilina, e-mail: vladimira.ziackova@fpedas.uniza.sk

* doc. Ing. Radovan Madleňák, PhD., Žilinská univerzita v Žiline, Fakulta prevádzky a ekonomiky dopravy a spojov, katedra spojov, Univerzitná 1, 01026 Žilina, e-mail: radovan.madlenak@fpedas.uniza.sk
} 
preferencií v danej oblasti? Na tieto otázky sa budeme snažit' odpovedat' práve v tomto článku.

\section{Charakteristika marketingového prieskumu}

Ciel'om prieskumu bolo určenie miery akceptácie jednotlivých druhov internetovej reklamy pre určitý zákaznícky segment. Ako typ prieskumu bol zvolený kvantitatívny prieskum. Ciel'ovou skupinou boli fyzické osoby vo všetkých vekových kategóriách. Pre zber údajov bola využitá metóda elektronického dopytovania. Hlavným prvkom použitej metódy sú aplikácie postupu reprezentatívneho dotazníkového prieskumu v prostredí internetu. Prieskum sa realizoval v období od 3. marec 2009 do 2.42009 na vzorke 208 respondentov.

\section{Stanovenie medznej miery akceptácie pre jednotlivé druhy display reklamy}

Zatial’ čo v predchádzajúci článok bol venovaný identifikovaniu miery akceptácie jednotlivých foriem reklamy, $v$ tejto časti je pozornost' zameraná na jednotlivé druhy reklamy zobrazovanej na obrazovke. Bolo použité členenie na bannerovú reklamu a doplnkové formáty display advetising a poznatky boli vyhodnocované zvlášt' pre tieto dve skupiny.

Analogicky bola určená medzná miera akceptácie:

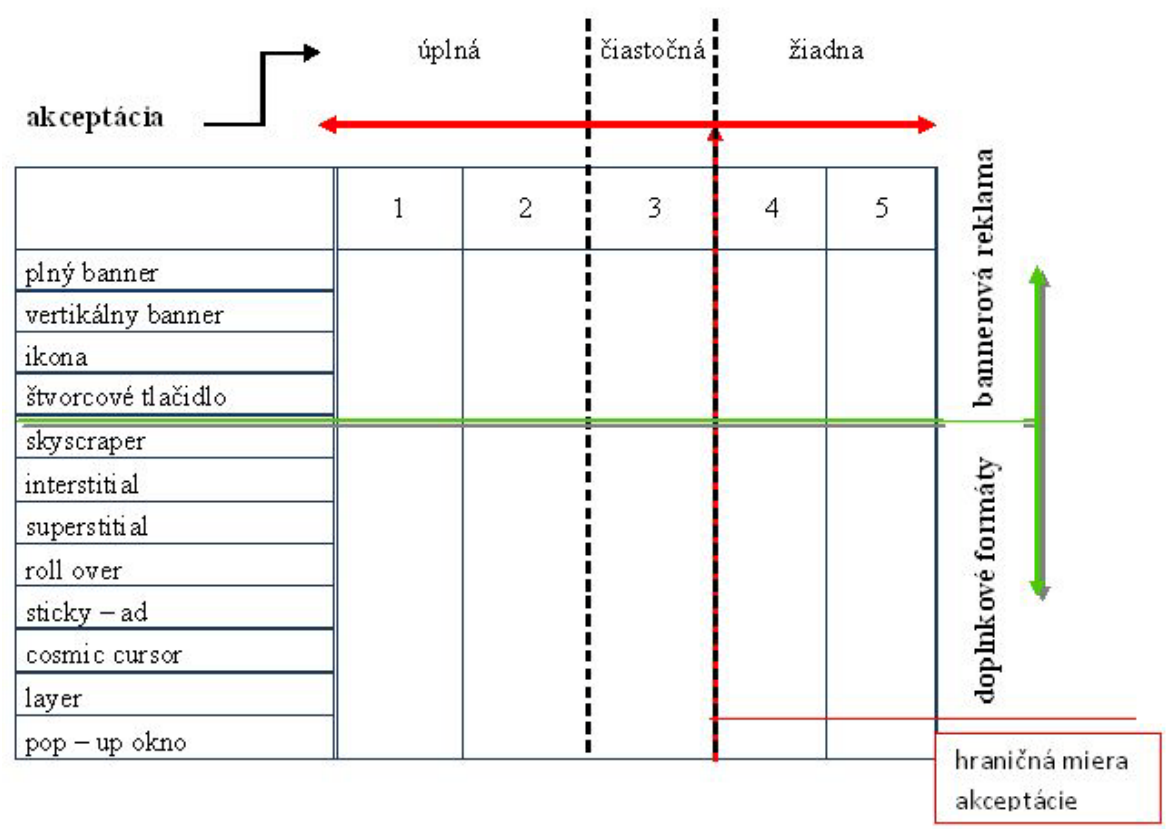

Obrázok 1. Určenie medznej miery akceptácie display advertising

Respondenti v prieskume odpovedali na otázku: „Prekážajú Vám určité typy reklamy zobrazovanej na obrazovke?“ a vyberali si z ponúkaných možností číselného hodnotenia, kde 1 znamená „vôbec neprekáža“ a 5 znamená „úplne prekáža“.

\section{Bannerová reklama}

Z predchádzajúcich prieskumov realizovaných v rovnakej oblasti [1,3,4] vyplýva, že za najzaujímavejšiu formu reklamy na internete považujú používatelia internetu banner s animovanými obrázkami, čo v realizovanom prieskume uviedlo až 55 \% respondentov. Ďalšie formy reklamy, ktoré pokladajú používatelia internetu za zaujímavé, sú: malé obrázkové ikony s odkazmi na iné stránky (35\%), banner s textom (29 \%) a banner so statickými obrázkami (26\%). [2]

$\mathrm{V}$ realizovanom prieskume nebola zohl'adnená interaktivita bannerov, čiastočne je však možné výsledky porovnat'. 
V rámci zist'ovania preferencií v oblasti hlavných prvkov vyvolávania záujmu o daný reklamný prvok sa zistilo, že animácia užívatel'ov zvoleného segmentu vôbec nedokáže zaujat'. Na druhej strane, bannery s textom a so statickými obrázkami je možné považovat' za prijatel'né medzi používatel'mi segmentu, ked’že väčšinu $\mathrm{z}$ nich dokáže reklamný banner zaujat' najmä svojím obsahom.

Užívatel'mi hodnotenú prijatel'nost' bannerovej reklamy zobrazíme graficky.

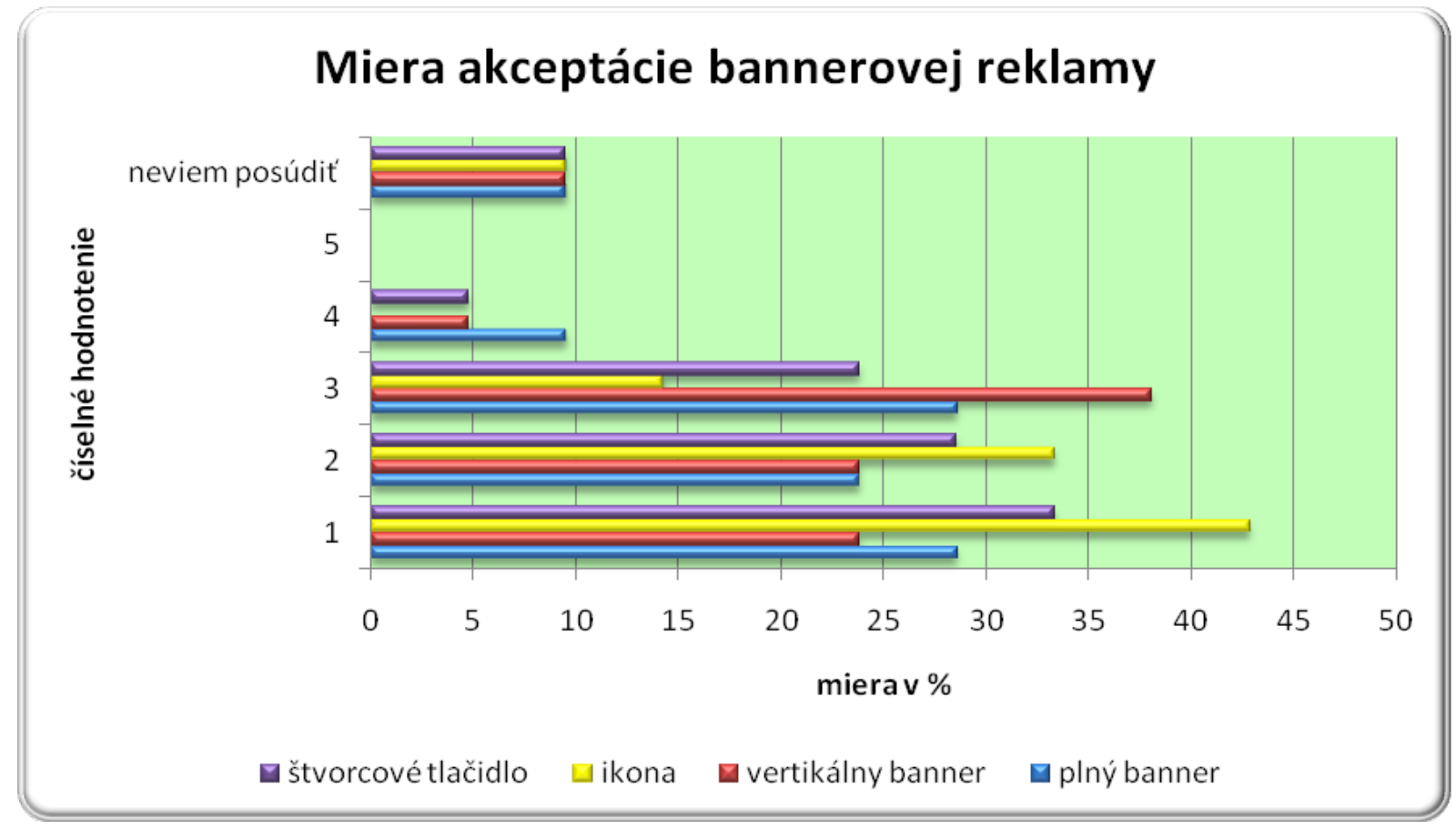

Obrázok 4. 5. Miera akceptácie bannerovej reklamy

Používatelia internetu zahrnutí v zvolenom segmente sú ochotní najviac akceptovat' najmenší formát bannerovej reklamy - ikonu, následne štvorcové tlačidlo a až potom plný a vertikálny banner. Za úplne prekážajúci nepovažujú žiaden z bannerov.

Po stanovenú medznú mieru sú konkrétne hodnoty miery akceptácie nasledujúce:

- plný banner - 80,95 \%,

- vertikálny banner - 85,72 \%,

- ikona - 90,48\%,

- štvorcové tlačidlo - 85,71 \%.

Hraničná miera je pri všetkých štyroch typoch bannerovej reklamy vysoká, takže pre tento typ reklamy môžeme súhrnne skonštatovat', že je medzi uživatel'mi akceptovatel'ný. Najväčší podiel užívatel'ov, ktorí akceptujú bannerovú reklamu sa prikláňa k ikone, ide až o $90,48 \%$.

\section{Doplnkové formáty display reklamy}

Pri určení miery akceptácie doplnkových formátov reklamy zobrazovanej na obrazovke ja vychádza z rovnakých druhov ako pri zist'ovaní preferencií užívatel'ov. 


\section{Miera akceptácie doplnkových formátov display advertising}

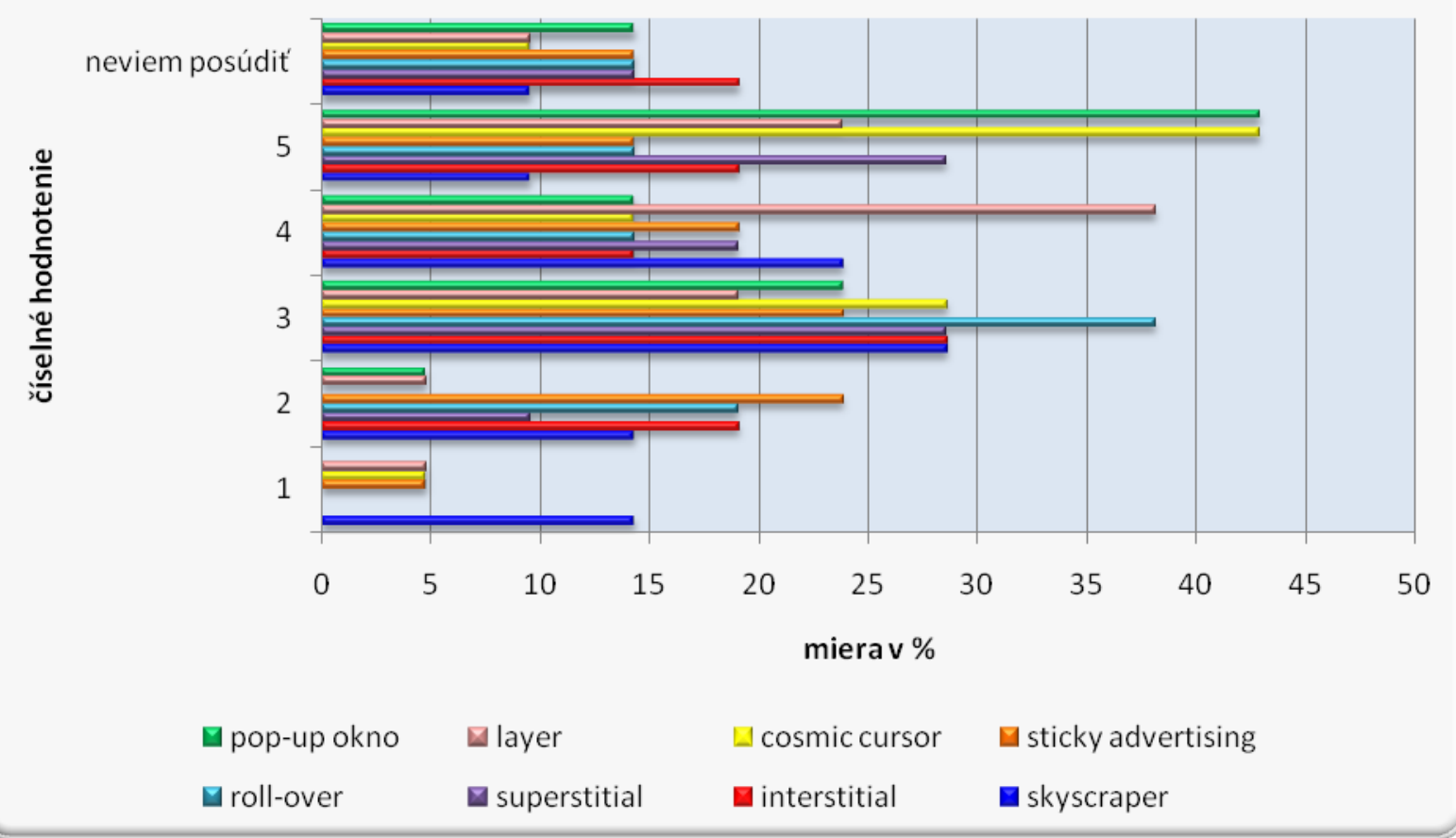

Obrázok 2. Miera akceptácie doplnkových formátov display advertising

Na základe porovnania s predchádzajúcim obrázkom je možné vyvodit’ jasný záver, že vybrané doplnkové formáty sú akceptovatel’né v omnoho menšej miere ako bežná bannerová reklama, ked’že miera akceptácie sa presunula zo spodnej časti grafu do horného kvadrantu. Konkrétne hodnoty hraničnej miery akceptovatel'nosti pre jednotlivé typy reklamy sú nasledovné:

- pop-up okno - 28,57 \%,

- layer - 28,57 \%,

- cosmic cursor - 33,33 \%,

- $\quad$ sticky-advertising - 52,38 \%,

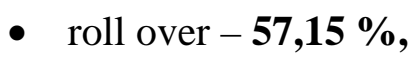

- superstitial - 38,09 \%,

- interstitial - 47,62 \%,

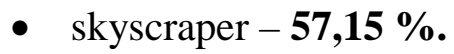

Najvyššie percento opýtaných sa prikláňa k ochote akceptovat' Skyscraper ako doplnkovú formu display advertising. Najneprijatel'nejšími druhmi tejto reklamy sú Layer ${ }^{1}$, Pop-up okno a Cosmic cursor, ktorý je istý čas „prilepený“ ku kurzoru myši. Respondenti označili ako prijatel'nejšie formy Roll over, Sticky-Ad a Skyscraper.

\section{Miera akceptovania emailovej reklamy}

V rámci zist'ovania miery akceptovatel'nosti reklamy zasielanej na emaily užívatel'ov sa táto charakteristika zist’ovala pre všetky typy tejto reklamy, konkrétne pre:

\footnotetext{
${ }^{1}$ posudzovaný ako najagresívnejší banner, pretože sa rozbalí cez celú stránku a po niekol'kých sekundách sa zbalí do menšieho formátu, ktorý je nestálo umiestnený na stránke
} 
- reklamné vsuvky vložené do bežného mailu,

- sponzorstvo diskusných skupín,

- autorizovanú reklamnú poštu.

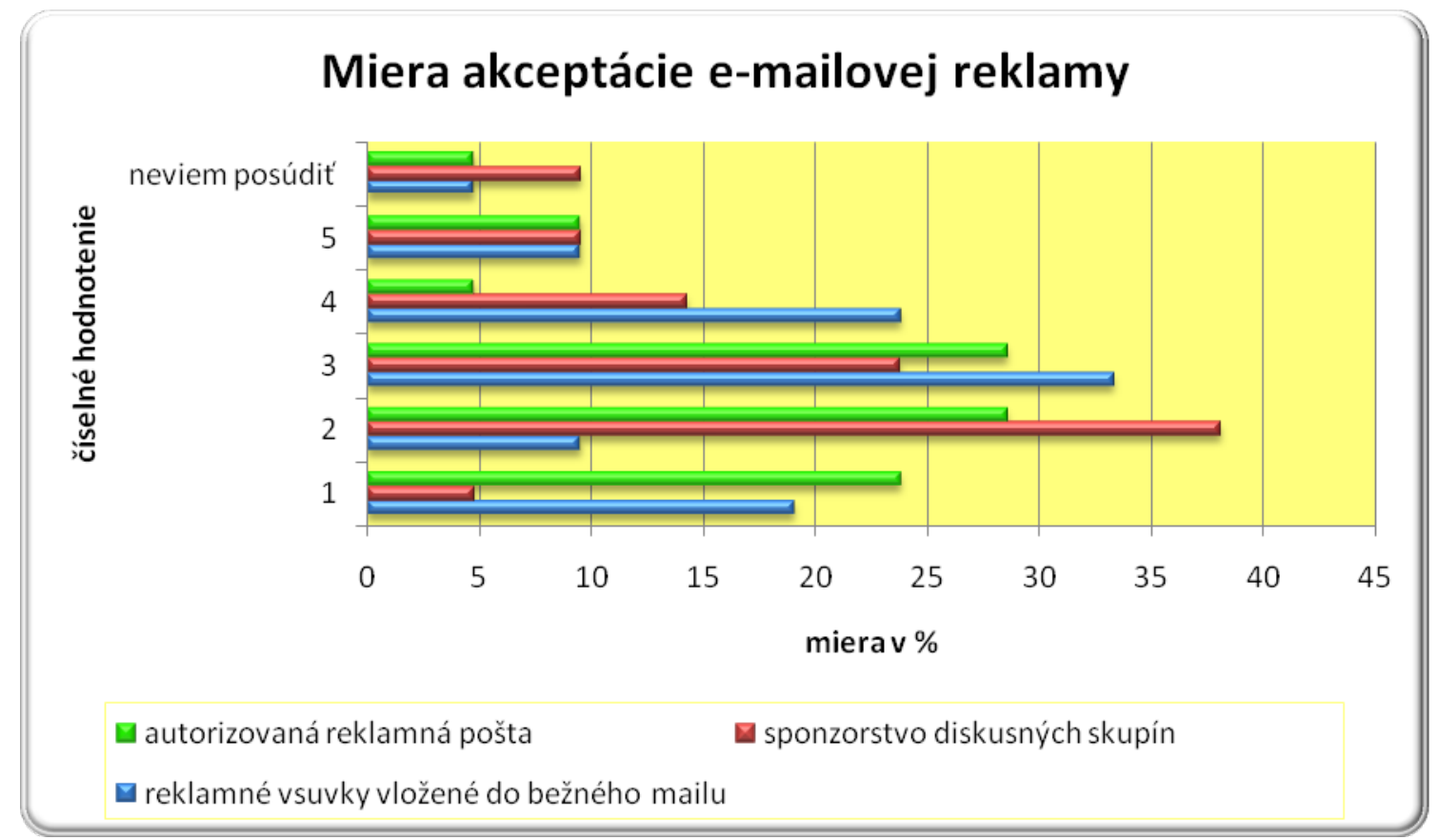

Obrázok 3. Miera akceptácie e-mailovej reklamy

Najprijatel'nejšou formou mailovej reklamy je autorizovaná reklamná pošta $(23,81 \%)$, čo je zrejmé, ked'že prijímatelia tejto pošty určitým spôsobom súhlasili s tým, že im na nimi uvedenú adresu môže byt' zasielaná reklamná pošta. Podobne dobré výsledky dosahujú i reklamné vsuvky vložené do bežného mailu (19,05 \%).

Sponzorstvo diskusných skupín považuje za prijatel’nú formu mailovej reklamy iba 4,76 \% respondentov. Je nutné však brat' do úvahy, že takmer $10 \%$ respondentov nevedelo posúdit' prijatel'nost' tejto reklamy. Novinky, ktoré sa objavia v diskusnej skupine, ktorej je príjemca reklamy členom, sú rozosielané všetkým účastníkov do ich mailových schránok. Každodenne však narastá množstvo takto doručovanej pošty, až do okamihu, kedy sa stane neúnosné a prijímatel' začne reklamu ignorovat', alebo sa z diskusnej skupiny odhlási úplne.

Hraničná miera akceptácie nadobúda tieto hodnoty:

- reklamné vsuvky vložené do bežného mailu - 61,90 \%,

- sponzorstvo diskusných skupín - 66,67 \%,

- autorizovaná reklamná pošta - 80,95 \%.

Z týchto hodnôt vyplýva, že prijímatelia emailovej pošty sú vo vysokej miere ochotní akceptovat' autorizovanú reklamnú poštu, ked’že so zasielaním takéhoto druhu reklamy určitým spôsobom súhlasili. Až 80,95 \% respondentov akceptuje autorizovanú reklamnú poštu ako spôsob zasielania reklamných oznamov. V menšej miere je akceptovatel'né sponzorstvo diskusných skupín a reklamné vsuvky vložené do bežného mailu, tieto hodnoty sú však tiež vysoké, takže používatelia internetu sú ochotní všetky formy emailovej reklamy akceptovat'. 


\section{Záver}

V online svete dokáže človek skoro okamžite zistit', čo funguje a čo naopak nie, čo je prijatel'né a čo úplne odmietané. Nová online reklama sa vyvíja a prispôsobuje technologickým inováciám a počtu prítomných užívatel'ov. Nejedná sa už len o plošnú reklamu v podobe bannerov, ale o vytváranie komplexných reklamných posolstiev prostredníctvom komunít a blogov a prepájanie online prostredia s klasickými médiami.

Každý reklamný prvok zverejnený na internetových stránkach je monitorovaný a vyhodnocovaný a tiež informácie o prekliknutí a presmerovaní na konkrétne ciel'ové stránky sú dostupné okamžite. Lepšia meratel'nost' je len jedna z výhod a mohli by sme pokračovat' pojmami ako interaktivita, blízkost' $\mathrm{k}$ užívatel'om, detailné cielenie, flexibilita, apod. Žiadnou výpočtovou technikou však nie je možné zmerat' konkrétne postoje uživatel'ov. Ciel'om série týchto článkov bolo zistit', v akej miere sú užívatelia zaradení do vybraného segmentu ochotní online reklamu akceptovat'.

\section{Literatúra}

[1] KOZEL, R.: Moderní marketingový výzkum. Grada Publishing, a. s., Praha, 2006. ISBN 80-247-0966-X.

[2] ŽIAČKOVÁ, V.: Identifikácia medznej miery akceptácie foriem internetovej reklamy prevybraný zákaznícky segment, Diplomová práca, 117/2009 KS, Katedra spojov, ŽU Žilina, 2009

[3] MADLEŇÁK, R..: Elektronický obchod. Vydavatel'stvo EDIS, Žilina, 2004. ISBN 808070-192-X.

[4] MADLEŇÁKOVÁ, L.: $\mathrm{K}$ problematike hodnotenia spokojnosti zákazníka, In: POSTPOINT 2005 : medzinárodná konferencia zástupcov poštových správ a univerzít, Katedra spojov, ŽU Žilina, Žilina 28. - 30. september 2005, ISBN 80-8070-454-6.

[5] ŠVADLENKA L. Management v poštovních službách. První vydání. Univerzita Pardubice, 2006. 121 s. ISBN 80-7194-714-8.

\section{Grantová podpora}

- VEGA 1/0757/09 "Metódy a techniky strategického manažmentu ako nástroje zvyšovania efektívnosti podniku"

- VEGA 1/0149/10 "Difúzne procesy nových mobilných služieb a ich hodnotový ret'azec"

- KEGA 036-017ŽU-4/2010 "Data modeling v procese vzdelávania v počítačovom laboratóriu Katedry spojov" 